\title{
Gibberellic Acid Activity in Sugarcane as a Function of the Number and Frequency of Applications
}

\author{
Alex G. Alexander, R. Montalvo-Zapata, and Ashok Kumar ${ }^{1}$
}

\section{INTRODUCTION}

The effects of gibberellic acid (GA) on sugarcane have been studied extensively throughout the sugarcane world $(1,2,3,4,5,6,7,8,11,15,16) .^{2}$ Given proper conditions for tissue penetration, GA will increase both tonnage and juice quality. Unfortunately, efforts to harness this chemical for the sugar industry have not been successful. In simplest terms there are two types of unresolved problems: 1, The economics and agronomics of field usage; and 2, the physiological limitations of GA potential.

GA research in Puerto Rico is performed primarily at the greenhouse and laboratory level. Emphasis is directed toward the enzymatic basis of GA action under a series of controlled physiological conditions. The GA treatments are usually centered around a single foliar application at one moderately high level. Although this approach describes the kinds of changes that GA can produce, the magnitude of change-and consequently the economic potential-rests ultimately on the efficiency of GA utilization. The present study was designed to yield more realistic information with regard to the number and frequency of applications needed for maximum response.

There were two primary objectives: 1 , The attainment of maximum growth in terms of millable stalks and 2, maximum sucrose production as reflected by increased sucrose content of millable stalks. In planning the treatments careful consideration was given to the critical GA attributes of tissue penetration and of post-stimulatory growth reversion. Assuming a limited adsorptive capacity of sugarcane leaves, it was theorized that a single massive application could not be fully assimilated. Therefore the use of split or cumulative applications was included. The concept of multiple application has been used by other workers in efforts to prolong growth stimulation. The primary difference here was that we were attempting both a higher growth maximum and prolonged growth activity on the basis of more efficient utilization of a single absolute quantity. Hence, the total amount of GA given was constant among all GA treatments regardless of application number.

1 Plant Physiologist, Assistant Chemist, and Assistant Biochemist, respectively, Agricultural Experiment Station, Mayagüez Campus, University of Puerto Rico, Río Piedras, P.R.

2 Italic numbers in parentheses refer to Literature Cited, p. 502-3. 
A second major consideration was the fact that GA-induced growth activity is followed by severe growth decline (b). This is characterized enzymatically by new behavior patterns in a distinct physiology producing less growth even than untreated controls. Although not specifically stated, the early work by Coleman et al. (11) implied that growth reversion to subnormal levels could have taken place. Data presented by Bull (6) also indicated possible growth reversion, although the experiments did not extend long enough for this to be seen clearly. In the authors' opinion, failure to recognize GA growth decline as something more than a "wearing off" or a return to normalcy, i.e., rather than as a new growth regime distinct both from controls and from the plants' own pretreatment period, accounts for many of the discrepancies in results with GA. Once this new regime is recognized it becomes clear that repeated applications are not necessarily efficient, nor would they be effective either in physiological or economic terms unless the time factor is carefully considered.

Distinct time variables were therefore incorporated into several GA increment evaluations. It was theorized that a cumulative series of GA increments should be most effective if the series were quickly completed, i.e., while the plants were still being "geared up" for growth, in essence allowing enough time for adsorption of each increment as a distinct entity but not enough time for growth decline to set in. Conversely, over extension of increment intervals might cancel much of the GA potential by reducing its role to that of a delaying action against an established growth decline. Stating this in simplest terms, it was thought that greater GA performance could be realized if all the GA was given to the plant while it was trying to grow, rather than withholding some GA until the plant was trying not to grow.

Although the GA treatments were designed for maximum growth effects, sugar responses were also of major concern. The work of Harber and Talbert (17) and of Hayashi (18) with radioactive $\mathrm{CO}_{2}$ suggests that GA has no effect on photosynthetic activity per unit of leaf area, even though increased photosynthetic efficiency was not ruled out. Leaf-sucrose data have implied that GA stimulates sucrose synthesis while growth activity is in progress $(1,2,5)$. In vitro experiments have shown that traces of GA will increase sucrose bio-synthesis by leaf homogenates (9). During a recent controlled-illumination study Alexander et al. (10) demonstrated that GA pretreatments vastly improved the sucrose-forming potential of sugarcane leaves. Similar leaf effects were noted in GA field studies designed for flower control $(5)$. Consequently, efforts were made to examine sucrose changes in the stalk and individual internodes, and to determine whether the GA treatment most effective for growth would also be optimum for sucrose. 


\section{EXPERIMENTAL PROCEDURE}

\section{GROWTH AND TREATMENT OF PLANT MATERIALS}

Plants of the variety P.R.980 were grown at the greenhouse in HClwashed quartz sand contained in 2-gallon stoneware pots. The technique has frequently been described in this Journal. The plants within each container received about 1 liter of nutrient solution ${ }^{3}$ and 1 liter of tapwater daily. At 10 weeks of age 72 containers were selected for uniformity from a total of 120. These were arranged in four groups of 18 containers each and GA treatments were initiated. At this time, hereafter designated as " 0 days", the third or fourth internode was emerging from sheath coverage.

There were four treatments, each applied to the leaves with a Hudson hand sprayer. The first, or control, consisted only of distilled water and the wetting agent Tween 20 . The second comprised a single application of 0.01 percent given at 0 days. A third treatment, consisting of 0.0033 percent GA, was given at 0,10 , and 20 days. The fourth treatment also involved three applications of 0.0033 percent each, but the latter were given at 0,35 , and 70 days. A randomized block design was employed with three replicates for each of the four treatments.

All of the GA solutions were made up in 2 liters of distilled water containing $2 \mathrm{ml}$. of Tween 20 . This volume still sufficed to wet all leaf areas at 70 days. ${ }^{4}$ Regardless of age and size differentials each of the three GA groups received in total an equal amount of GA.

\section{ANALYSES}

Samples were harvested for growth and sugar analyses at $0,14,28,42$, $56,70,84,106$, and 120 days after initial GA applications. Two uniform plants from each replicate were cut at the sand surface. At the final harvest six plants were taken from each replicate. Total green weight and weight of millable stalks was recorded immediately. The "millable stalk" discussed herein included internodes extending to about leaf +4 in the green-leaf area. This represents about two internodes more than would be taken by a cane cutter in the field, but nonetheless it provides useful growth and sugar information in a study of this sort. Individual internode lengths were recorded within an hour after harvest and stalks were then stored in a freezer. Stalks from each successive harvest were frozen until all sampling

- Nutrient concentrations, expressed as milliequivalents per liter, were provided as follows: Nitrate, 10; phosphate, 6; potassium, 5; calcium, 3; magnesium, 2, and sulfate, 2; microelements, expressed as parts per million, were given as follows: Boron, 0.05; copper, 0.02; manganese, 0.50 ; zinc, 0.05 ; molybdenum, 0.01 , and iron, 1.0 .

- Although individual plants were vastly enlarged during this period, the total number of plants remaining per treatment population continually declined. 
was completed. The samples were then removed from the freezer, thawed over a 3-hour period at room temperature, and milled for Brix and polarization analyses. ${ }^{5}$

By far the most important harvest was the final one taken at 120 days. In effect each stalk was a map of growth changes transpiring during the previous 4 months. At this time, in addition to length measurements, the diameter of each internode was measured midway between successive nodes. A composite of 10 additional stalks from each treatment was subdivided into individual internodes and each group was then ground separately in a small laboratory mill. Juice samples were used for Brix and polarization analyses, for direct sucrose assay, and for evaluation by paper chromatography.

TABLE 1.-Total green weight, in grams per plant, of immature sugarcane subjected to variables of $G A$ concentration, number of $G A$ applications and frequency of GA applications 1

\begin{tabular}{|c|c|c|c|c|c|c|c|c|c|c|c|}
\hline \multirow{2}{*}{$\begin{array}{c}\text { GA level } \\
\text { (percent solution) }\end{array}$} & \multirow{2}{*}{$\begin{array}{c}\text { Frequency } \\
\text { applied } \\
\text { (days) }\end{array}$} & \multicolumn{9}{|c|}{ Days after initial treatment- } & \multirow{2}{*}{ Mean } \\
\hline & & $\mathbf{0}$ & 14 & 28 & 42 & 56 & 70 & 84 & 106 & 120 & \\
\hline 0 (Control) & $\mathbf{0}$ & 128 & 184 & 293 & 316 & 364 & 442 & 564 & 512 & 496 & 367 \\
\hline $.01 \quad(1)$ & & 118 & 257 & 310 & 376 & 536 & 496 & 539 & 639 & 632 & 434 \\
\hline $.0033(3)$ & $0,10,20$ & 149 & 232 & 361 & 469 & 562 & 572 & 662 & 657 & 688 & 484 \\
\hline $.0033(3)$ & $0,35,70$ & 134 & 239 & 319 & 420 & 487 & 482 & 557 & 651 & 652 & 438 \\
\hline \multicolumn{2}{|c|}{ GA Mean } & 134 & 243 & 330 & 422 & 528 & 517 & 586 & 649 & 657 & \\
\hline
\end{tabular}

1 Each figure represents the mean of 3 replicates. Two uniform plants were harvested from each replicate. At the final harvest 6 plants were taken from each replicate.

Juice was clarified by prolonged centrifuging and assayed for sucrose by the resorcinol method of Cardini et al. (12). Other samples were chromatographed on Whatman no. 1 filter paper using the solvent mixture butanolpyridine-water $(6: 4: 3, \mathrm{v} / \mathrm{v})$ in one dimension. Reference and unknown sugar spots were developed by the silver nitrate method of Dube and Nordin (14).

5 The freezing of cane juice apparently reduces its natural buffering capacity (18), leading to more rapid deterioration than is expected of freshly-milled juice. For the present study all samples were milled and assayed before appreciable sucrose losses could occur. The technique of freezing stalk samples until all harvests are complete is more than just convenient because all stalks can then be milled with small operational variables being confined to a single period. 


\section{RESULTS AND DISCUSSION}

This study verified that the use of GA increments, and the timing of GA increments, vastly altered the capacity of a single GA quantity to affect growth. Major sugar transformations occurred in storage tissue as a consequence of foliar GA treatments.

Nearly all of the senior author's work has been based on enzyme behavior, and more often than not this is an unknown quantity until long after the final harvest is taken. During the present study, however, important growth changes could be followed by careful and frequent observation of the living plants. For several weeks after 0 days the single 0.01 percent treatment was clearly outproducing the others. At the close of the study the 0-, 35-, and 70-day increments seemed still to be responding to GA. In general, taking the 4-month period as a whole, the 0-, 10-, and 20-day treatment was visibly superior to all others. This observation was sustained by growth and sugar data.

GROWTH RESPONSES TO GA

\section{Total Green Weights}

All of the GA treatments produced more green weight than controls (table 1). The GA effect was already measurable at 14 days, and by 28 days the 0-, 10-, and 20-day treatment established a growth lead which was retained throughout the remainder of the study. Green-weight production did not vary appreciably between the single 0.01 percent treatment and increment applications extending over a 70-day period.

\section{Internode Elongation}

Internode data presented in table 2 and illustrated by figure 1 were considerably more revealing with regard to GA activity. Internodes were significantly lengthened at an earlier period by the 0.01 percent treatment, as evidenced by internodes 4 and 5 , table 2 , but by internode 6 growth decline had already begun. The closely-spaced increments, at 0,10 , and 20 days, produced greatest elongation for internodes 6 through 10. Internodes 11 to 14 were slightly longer for the widely-spaced increments, at 0,35 , and 70 days.

The three closely-spaced applications of 0.0033 percent each (fig. 1,B) led to greater absolute elongation than a single dose of 0.01 percent (fig. 1,A). This was an average maximum of 8.6 inches as compared to 7.4 inches. Furthermore, the positive growth response extended over a longer growth-time interval (seven internodes for increments as compared to four internodes for a single application). As a consequence the period of subnormal growth was proportionately shortened, even though the slope 
TABLE 2.-Differential elongation of sugarcane internodes as a function of GA level, number of GA applications, and frequency of GA applications ${ }^{1}$

\begin{tabular}{|c|c|c|c|c|c|c|c|c|c|c|c|c|c|c|c|c|}
\hline \multirow{2}{*}{$\begin{array}{c}\text { GA level } \\
\text { (percent solution) }\end{array}$} & \multirow{2}{*}{$\begin{array}{c}\text { GA frequency } \\
\text { (days) }\end{array}$} & \multicolumn{14}{|c|}{ Length, in inches, for internode number- } & \multirow{2}{*}{ Mean } \\
\hline & & 1 & 2 & 3 & 4 & 5 & 6 & 7 & 8 & 9 & 10 & 11 & 12 & 13 & 14 & \\
\hline 0 (Control) & 0 & 1.0 & 2.3 & 3.3 & 3.7 & 4.0 & 4.2 & 4.1 & 4.0 & 3.9 & 4.1 & 4.2 & 3.9 & 4.3 & 4.4 & 3.7 \\
\hline $.01 \quad(1)$ & $\mathbf{0}$ & .9 & 2.1 & 3.5 & 6.0 & 7.4 & 6.4 & 5.3 & 4.3 & 3.4 & 3.5 & 3.6 & 3.8 & 3.8 & 3.8 & 4.1 \\
\hline $.0033(3)$ & $0,10,20$ & .8 & 2.1 & 3.2 & 4.7 & 6.1 & 7.6 & 8.6 & 8.2 & 6.7 & 5.4 & 4.2 & 3.3 & 3.0 & 3.1 & 4.8 \\
\hline $.0033(3)$ & $0,35,70$ & .7 & 2.3 & 3.2 & 4.7 & 6.1 & 6.6 & $\mathbf{5 . 3}$ & 4.5 & 5.1 & 4.9 & 4.6 & 5.1 & 5.4 & 4.7 & 4.5 \\
\hline \multicolumn{2}{|c|}{ GA Mean } & 0.8 & 2.1 & 3.3 & 5.1 & 6.5 & 6.9 & 6.4 & 5.7 & 5.1 & 4.6 & 4.1 & 4.1 & 4.1 & 3.9 & \\
\hline
\end{tabular}

1 Each figure represents the mean of 3 replicates. 
of growth decline was essentially constant among all GA treatments. This strongly supports the thesis that cumulative growth stimulation can accede to levels unattainable with a single application. ${ }^{6}$

In marked contrast was the internode pattern for widely-spaced increments (fig. 1,C). Not only did maximum elongation fall short of that achieved by 0.01 percent GA, i.e., only 6.1 inches as compared to 7.4 inches, but subsequent increments gave only a partial check to the growth decline without regaining appreciable growth stimulation. One could surmise that two-thirds of the chemical was expended in preserving a part of an already limited growth stimulation gained by the initial one-third.

It is recognized that GA applied to field cane initiates similar growthstimulatory and growth-reversion regimes (5). Since the quantity of GA that a producer can provide to a given acreage is limited by economic and mechanical factors, the success of GA usage might easily hinge upon the timing of its application. Stating this another way, a producer could be fully aware of a need for GA, and of a need for multiple GA applications, and still lack the information needed for effective GA usage.

\section{Stalk Weights}

In the foregoing section it was implied that the GA stimulation of internode length could be taken as a measure of tonnage potential as well. A logical question is whether GA does in fact increase growth per se or does it simply lengthen tissues being produced at an otherwise constant rate. Both stalk weights and internode-diameter measurements confirmed that GA increased overall growth.

A glance at stalk weights recorded in table 3 confirms that all GA treatments increased growth in comparison with controls, and that among GA treatments the use of closely-spaced increments was clearly superior. Mean values indicate that widely-spaced increments gave no appreciable growth increases over those of the single 0.01 percent treatment. Speaking again in an academic sense, similar increases in the field from widely-spaced increments would not seem to justify the cost of two additional applications.

- In the original drawings for figure 1, those areas denoting growth responses above or below control levels were conveniently estimated by use of a grid having 5 squares to the centimeter. For $A, B$, and $C$, the area increases were $2.25,4.40$, and 2.40 square centimeters, respectively. Subtraction of subnormal growth areas yielded final net values of $1.52,3.92$, and 2.40 square centimeters, respectively. Therefore the additional growth gained by short-term increments, even after allowances for later growth decline, still exceeded the growth from long-term increments by 1.52 square centimeters, an area equal to the entire net gain by the single GA application. While the use of widely-spaced increments seemed to give an increase of 0.88 square centimeters when compared with a single GA application, there was in fact a loss of 1.52 square centimeters due to inefficient use of the frequency factor. 
Figure 2 illustrates the positive effects of all GA treatments on stalk weights during the 4 months following initial applications. Each of the GA treatments achieved a maximum response between 42 and 56 days. For the 0.01 percent treatment this optimum level was very brief and only modest increases over control values were recorded for the remainder of the study

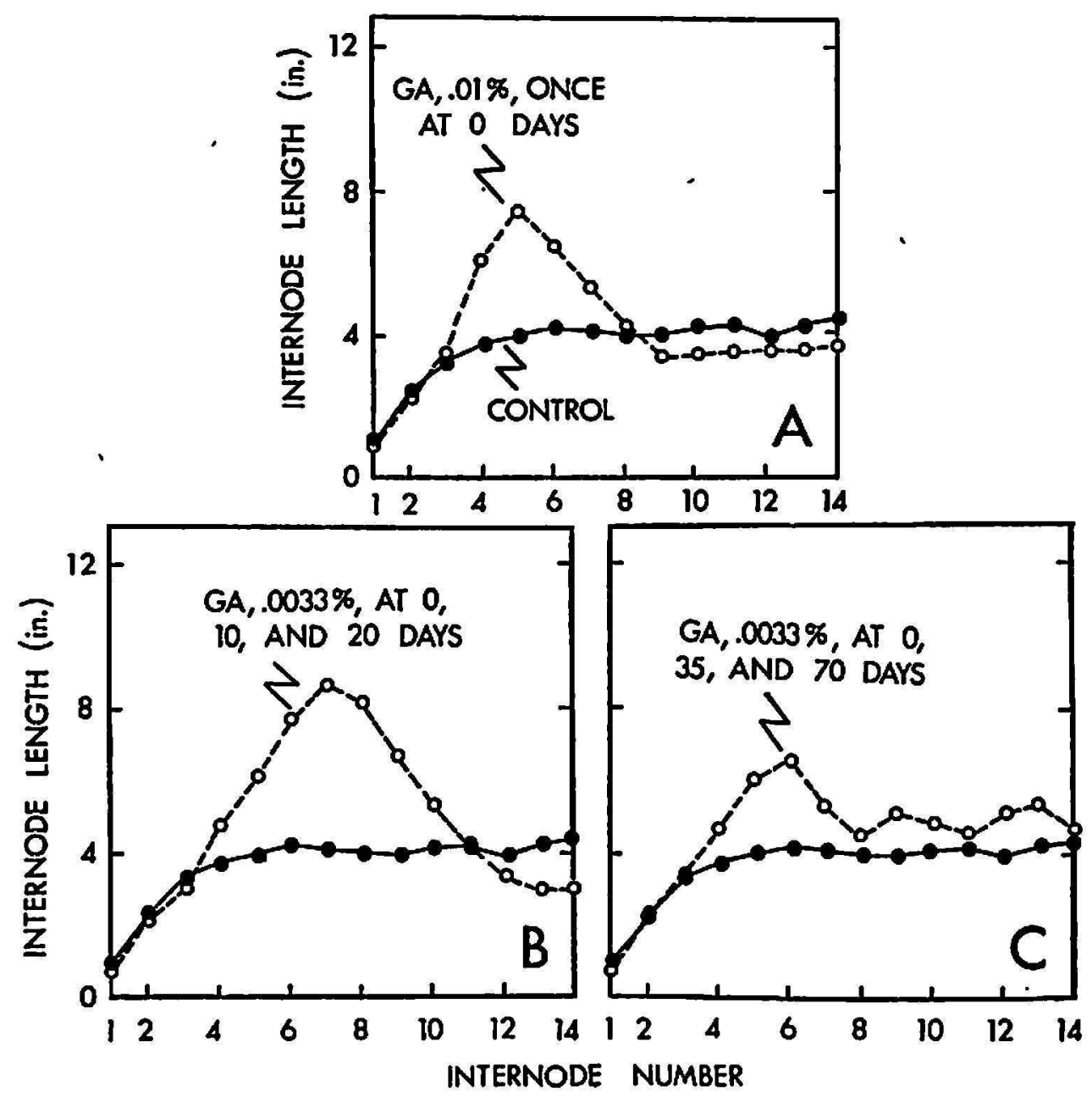

Fra. 1.-Internode elongation for sugarcane treated with foliar GA: A, One application, 0.01 percent; $B$, GA applied in 3 increments of 0.0033 percent each at intervals of 0,10 , and 20 days; $C$, GA applied in 3 increments of 0.0033 percent each at intervals of 0,35 , and 70 days.

(fig. 2,A). The superiority of closely-spaced GA increments is attributed first to a greater optimum weight achievement at 56 days, and second to a retention of this broad differential throughout the ensuing 2 months (fig. $2, \mathrm{~B})$. $^{7}$

In the original drawings for figure 2, areas denoting stalk-weight increases for $\mathrm{A}, \mathrm{B}$, and $\mathrm{C}$ were $3.08,8.04$, and 4.08 square centimeters, respectively. Apparent gain for broadly-spaced increments was 1.00 square centimeter, whereas in fact a loss of 3.96 square centimeters was experienced due to inefficient timing of GA penetration. 
The use of widely-spaced GA increments failed to induce either the magnitude or perseverance of weight increases achieved by short-term increments (fig. 2,C). This is a most important observation. It tells us that because one GA treatment was incremented during a regime of advancing growth, it effectively transcended a remote position in time, and outproduced other GA having a closer position in time but burdened by a declining growth regime. The long-term increments were slightly superior to the single 0.01 percent application.

It is interesting to note that internode-length values reflect more precisely the receipt of specific GA applications. In particular there were three distinct internode peaks for widely-spaced increments (fig. 1,C), while only

TABLE 3.-Millable stalle weights of immature sugarcane subjected to variables of GA concentration, number of GA applications and frequency of GA applications ${ }^{1}$

\begin{tabular}{|c|c|c|c|c|c|c|c|c|c|c|c|}
\hline \multirow{3}{*}{$\begin{array}{c}\text { GA level } \\
\text { (percent solution) }\end{array}$} & \multirow{3}{*}{$\begin{array}{l}\text { Frequency } \\
\text { applied } \\
\text { (days) }\end{array}$} & \multicolumn{9}{|c|}{ Days after initial treatment- } & \multirow{3}{*}{ Mean } \\
\hline & & 0 & 14 & 28 & 42 & 56 & 70 & 84 & 106 & 120 & \\
\hline & & \multicolumn{9}{|c|}{ Grams per stalk } & \\
\hline 0 (Control) & $\mathbf{0}$ & 44 & 66 & 114 & 135 & 184 & 213 & 296 & 310 & 319 & 187 \\
\hline $.01 \quad(1)$ & & 37 & 107 & 143 & 191 & 332 & 276 & 319 & 375 & 422 & 245 \\
\hline $.0033(3)$ & $0,10,20$ & 47 & 97 & 156 & 258 & 384 & 383 & 442 & 448 & 484 & 300 \\
\hline $.0033(3)$ & $0,35,70$ & 47 & 94 & 147 & 231 & 281 & 272 & 338 & 448 & 450 & 256 \\
\hline \multicolumn{2}{|c|}{ GA Mean } & 44 & 99 & 149 & 227 & 332 & 310 & 366 & 424 & 452 & \\
\hline
\end{tabular}

1 Each figure represents the mean of 3 replicates. Two plants were harvested from each. At the final harvest 6 plants were taken from each replicate.

two indistinct peaks were evident on a stalk-weight basis (fig. 2,C). Internode lengths also indicate a greater degree of growth decline than is evident on a stalk-weight basis. Nonetheless, the values for green weights, internode lengths, and millable-stalk weights all tell an essentially constant story of GA superiority over no GA, and of short-term GA increments outproducing other means of GA application.

\section{Internode Diameter}

When viewing GA-treated cane in the greenhouse one sometimes feels that internodes have been excessively lengthened, in essence drawn out like a piece of heated glass tubing, with the result that the stalk has become

Additional weight gained by use of closely-spaced increments, or 4.96 square centimeters, exceeded the entire weight gain from a single GA application, i.e., 3.08 square centimeters. 
unnaturally thin. In fact this may well be true of some individual plants. However, current measurements have shown that internodes can be thickened during the growth-stimulatory phase, and that thickening is accentuated during the period of subnormal growth.

Internode-diameter values summarized in table 4 reveal that all GA

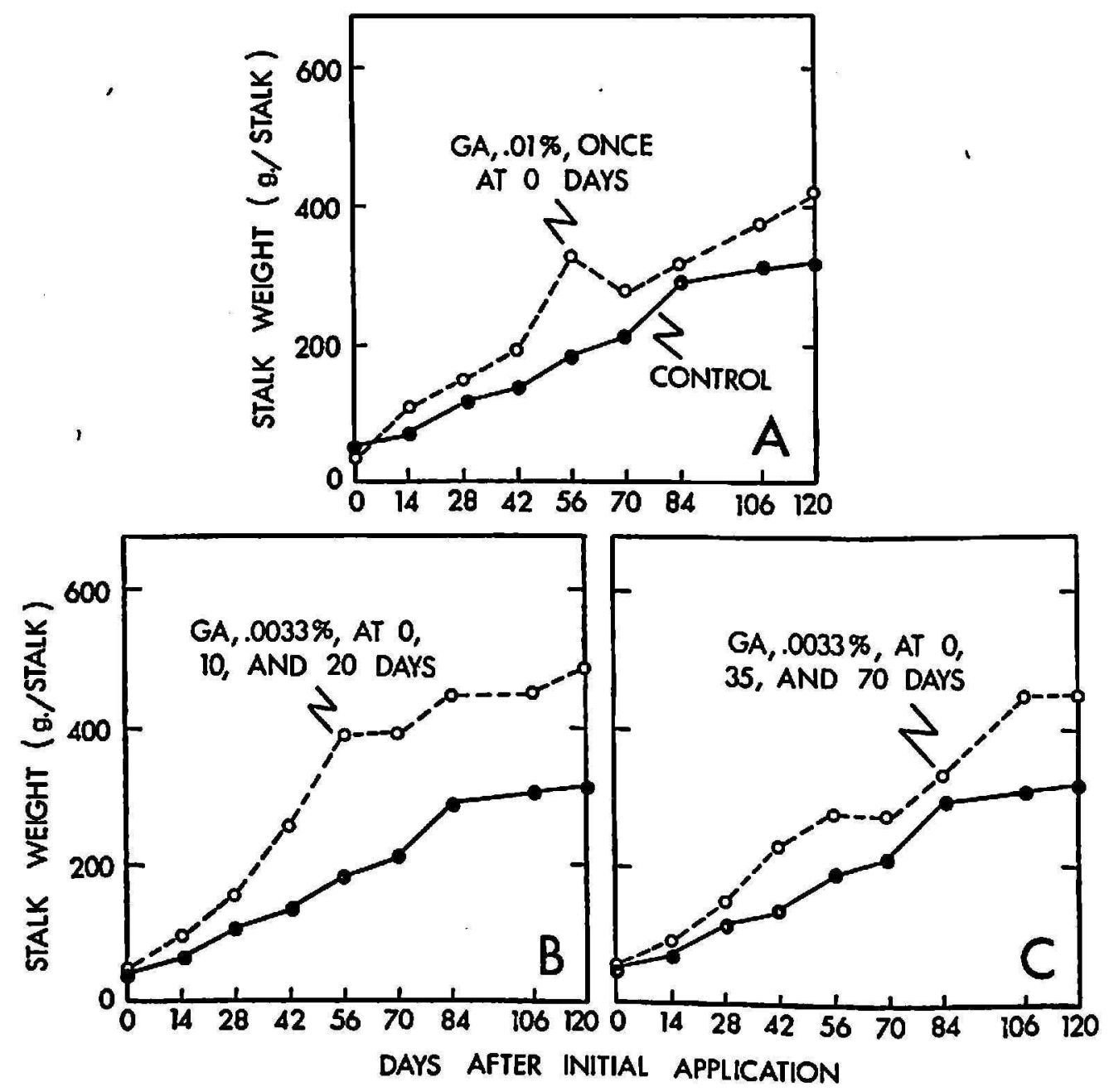

Fig. 2.-Increased stalk weights for sugarcane treated with foliar GA: A, GA applied once as a 0.01 percent solution; $B, G A$ applied in 3 increments of 0.0033 percent each at 0,10 , and 20 days; C, GA applied in 3 increments of 0.0033 percent each at 0 , 35 , and 70 days.

treatments led to lateral growth increases. In this respect the single 0.01 percent treatment was superior to all others. Figure 3 illustrates quite vividly the time and degree of lateral growth responses. For both the single and widely-spaced applications (fig. 3,A and C), internode thickening was essentially a function of longitudinal growth decline. For these treatments perceptible diameter increases began just after elongation rates had reached their maximum levels. The short-term GA increments produced lateral growth concurrently with both internode elongation and decline. It is 
T.MLE 4.-Diameler differenlials for sugarcane inlernodes as a function of GA level, number of GA applications, and frequency of GA applications ${ }^{1}$

\begin{tabular}{|c|c|c|c|c|c|c|c|c|c|c|c|c|c|c|c|c|}
\hline \multirow{2}{*}{$\begin{array}{c}\text { GA level } \\
\text { (percent solution) }\end{array}$} & \multirow{2}{*}{$\begin{array}{c}\text { GA irejuency } \\
\text { (days) }\end{array}$} & \multicolumn{14}{|c|}{ Diameter, in millimeters, for internode number- } & \multirow{2}{*}{ MIean } \\
\hline & & 1 & 2 & 3 & 4 & 5 & 6 & i & 8 & ) & 10 & 11 & 12 & 13 & 14 & \\
\hline 0 (Control) & 0 & 12.3 & 13.3 & 14.9 & 15.7 & 16.2 & 16.3 & 16.5 & 16.5 & 16.6 & 16.7 & 17.2 & 17.3 & 17.6 & 17.4 & 16.0 \\
\hline $.01 \quad(1)$ & 0 & 11.8 & 13.5 & 14.7 & 14.7 & 16.3 & 17.8 & 18.4 & 18.8 & 19.4 & 19.8 & 19.9 & 20.5 & 20.2 & 19.2 & 17.5 \\
\hline $.0033(3)$ & $0,10,20$ & 12.6 & 14.5 & 15.9 & 16.9 & 16.9 & 17.8 & 17.8 & 18.2 & 18.1 & 18.8 & 18.9 & 19.0 & 18.1 & 18.0 & 17.3 \\
\hline $.0033(3)$ & $0,35,70$ & 11.1 & $12 .(j$ & 13.9 & 15.3 & 15.9 & 17.1 & 17.6 & 17.8 & 17.3 & 17.7 & 18.2 & 18.4 & 18.8 & 19.1 & 16.5 \\
\hline \multicolumn{2}{|c|}{ (iA Mean } & 11.8 & 13.5 & 14.8 & 15.6 & 16.4 & 17.6 & 17.9 & 18.3 & 18.3 & 18.8 & 19.0 & 19.3 & 19.0 & 18.8 & \\
\hline
\end{tabular}

1 Each figure represents the mean of 3 replicates. 
logical that this thickening of internodes helped to increase the total weight productivity of the superior GA treatment, while retarding the weight losses of less effective ones. However, lateral growth did not fully compensate for absolute weight losses by the inferior GA treatments, i.e., by the single and widely-spaced applications (see fig. 2,A and C). On the other hand, lateral thickening very nearly did compensate for elongation decline

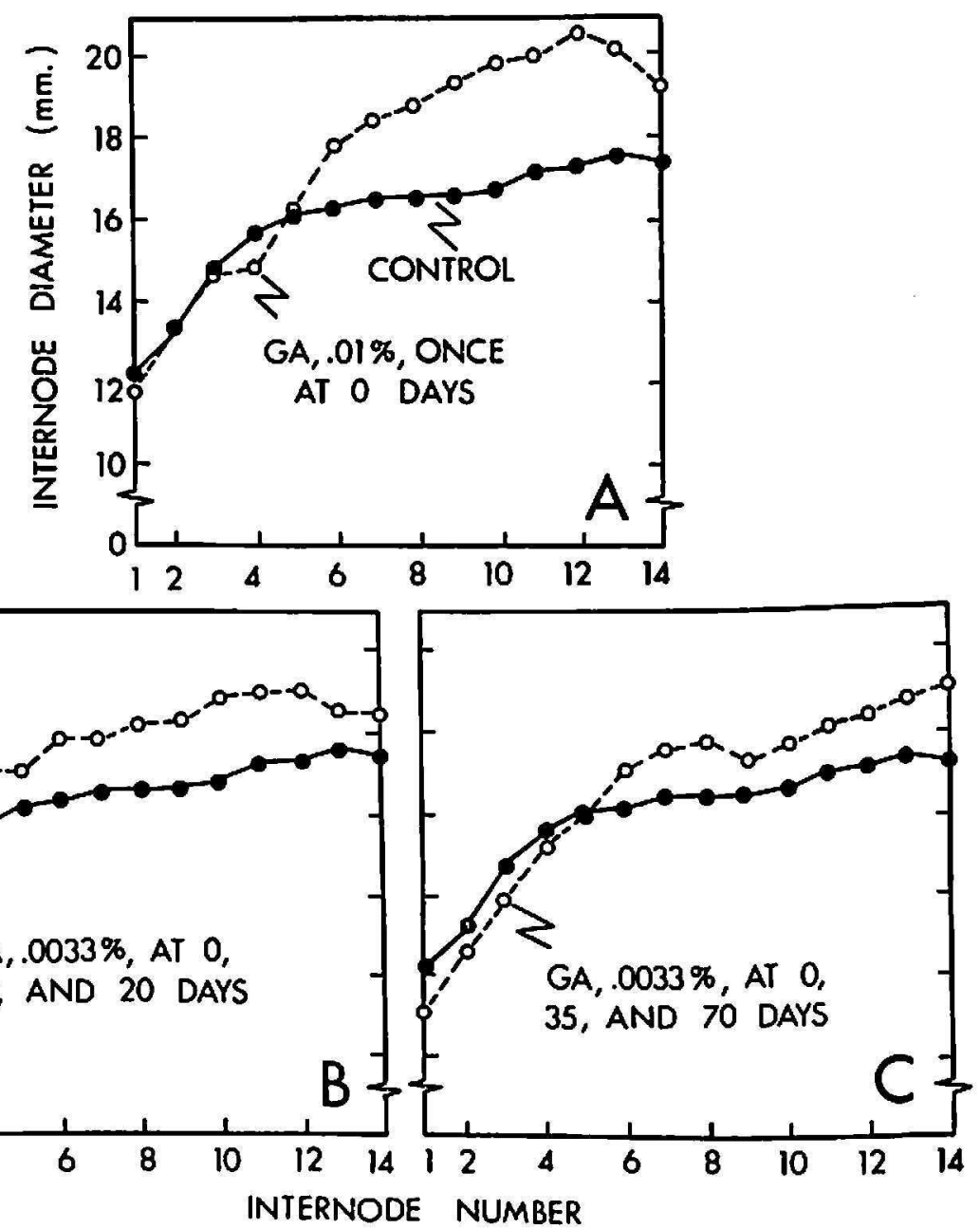

FIG. 3.--Increased internode dinmeter for sugarcane treated with foliar GA: A, GA applied once, 0.01 percent, at 0 days; $B, 3$ increments of 0.0033 percent each at 0,10 , and 20 days; $C, 3$ increments of 0.0033 percent each at 0,35 , and 70 days.

following the closely-spaced applications. This is a very important "plus" factor favoring the latter treatment. It again underscores a need for careful timing of GA penetration, and in this instance the growth criteria is not readily discernible by visual observation.

Stall: Splitting in Response to GA

A potentially serious problem observed repeatedly with GA in greenhouse studies is a vertical rending of internodes during, or immediately 
following, the period of rapid elongation. A typical internode in this condition is illustrated by figure 4 . It is frequently noted in response to 0.01 or 0.10 percent GA, with one to three damaged internodes per treated stalk being quite common. Previously this has been dismissed as a consequence of too much GA causing too much growth too quickly.

Internodal splitting also occurred during the present study, but almost

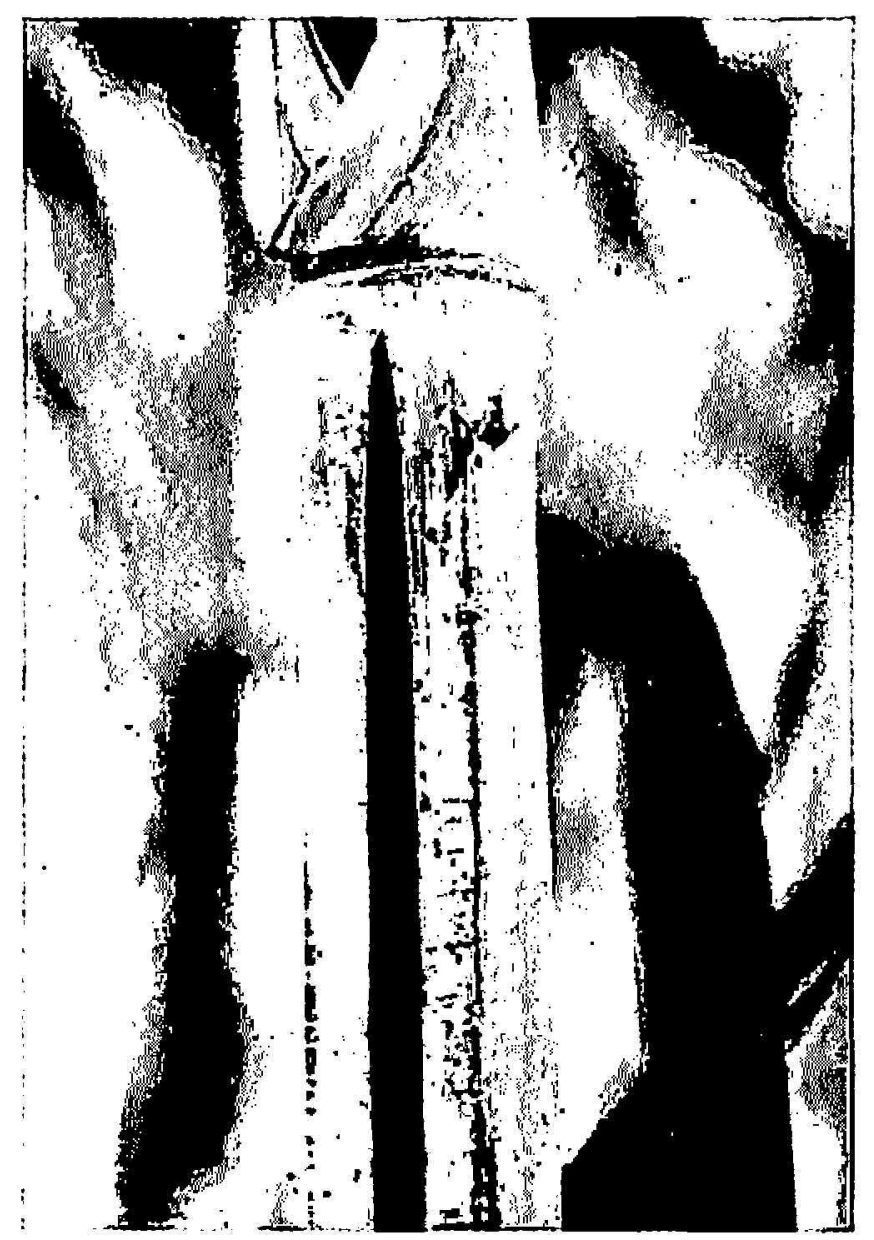

Fra. 4.-Internodal splitting of a sugarcane plant treated with 0.01 percent GA in a single application. Plants receiving an equal amount of GA in several increments were not damaged.

exclusively among the plants given 0.01 percent $\mathrm{GA}$ in a single dose. Although much more rapid growth rates were achieved with closely-spaced GA increments, this growth seldom produced a damaged internode. Thus, growth rate per se does not seem to be the most critical factor. Rather, the high concentration of GA incorporating into the tissue's physiology at a given moment is later reflected in distinct structural limitations. Again the time interval for reception of an absolute $\mathrm{GA}$ quantity appears to be a significant factor in successful GA usage. 


\section{SUGAR RESPONSES TO GA}

Sugar analyses of milled juice showed that GA either had accomplished modest sugar increases or had maintained levels in proportion to control plants after 4 months of treatment. Coupled with "tonnage" increases the absolute values for sucrose were clearly positive among GA treatments. The frequency of GA application had less effect on sugars than on growth.

\section{Brix and Polarization Values}

Table 5 summarizes Brix and polarization values recorded for the first and final harvests. Both the single GA application and widely-spaced increments led to moderate increases over control values during the 4 -month

TABLE 5.-Brix and polarization values for milled juice of immalure sugarcane trealed with foliar $G^{1}$

\begin{tabular}{|c|c|c|c|c|c|}
\hline \multirow{2}{*}{$\begin{array}{c}\text { GA level } \\
\text { (percent solution) }\end{array}$} & \multirow{2}{*}{$\begin{array}{l}\text { GA frequency } \\
\text { (days) }\end{array}$} & \multicolumn{2}{|c|}{ Brix- } & \multicolumn{2}{|c|}{ Polarization- } \\
\hline & & 0 days & 120 days & 0 days & 120 days \\
\hline 0 (Control) & $\mathbf{0}$ & 6.0 & 13.9 & 12.0 & 44.8 \\
\hline $.01 \quad(1)$ & 0 & 5.4 & 15.1 & 9.5 & 49.1 \\
\hline $.0033(3)$ & $0,10,20$ & 5.1 & 13.6 & 8.7 & 41.8 \\
\hline $.0033(3)$ & $0,35,70$ & 6.5 & 15.3 & 13.8 & 49.4 \\
\hline \multicolumn{2}{|c|}{ GA Mean } & 5.7 & 15.0 & 10.7 & 46.8 \\
\hline
\end{tabular}

1 Each figure represents the mean of 3 replicates. Two plants were harvested from each replicate at 0 days, and 6 plants at 120 days.

interval. The closely-spaced increments which had produced superior growth made sugar increases comparable to controls.

Analyses of individual internodes at the final harvest gave highly instructive information (table 6). Brix and polarization values were notably low in all GA-treated cane for internodes 2, 3, and 4 . These were the tissues already laid down or in the process of maturation when GA was first applied. From internode 6 to 12 the values from GA-treated cane were usually equal to or greater than controls.

\section{Sucrose}

Sucrose analyses of milled juice from individual internodes generally confirm the Brix and polarization data (table 7, figure 5). Sucrose levels were definitely low among the oldest internodes of GA-treated cane. The much larger internodes laid down thereafter generally contained more sucrose than those of control plants.

Table 7 includes estimates of sucrose-yield potential, for the 4-month 


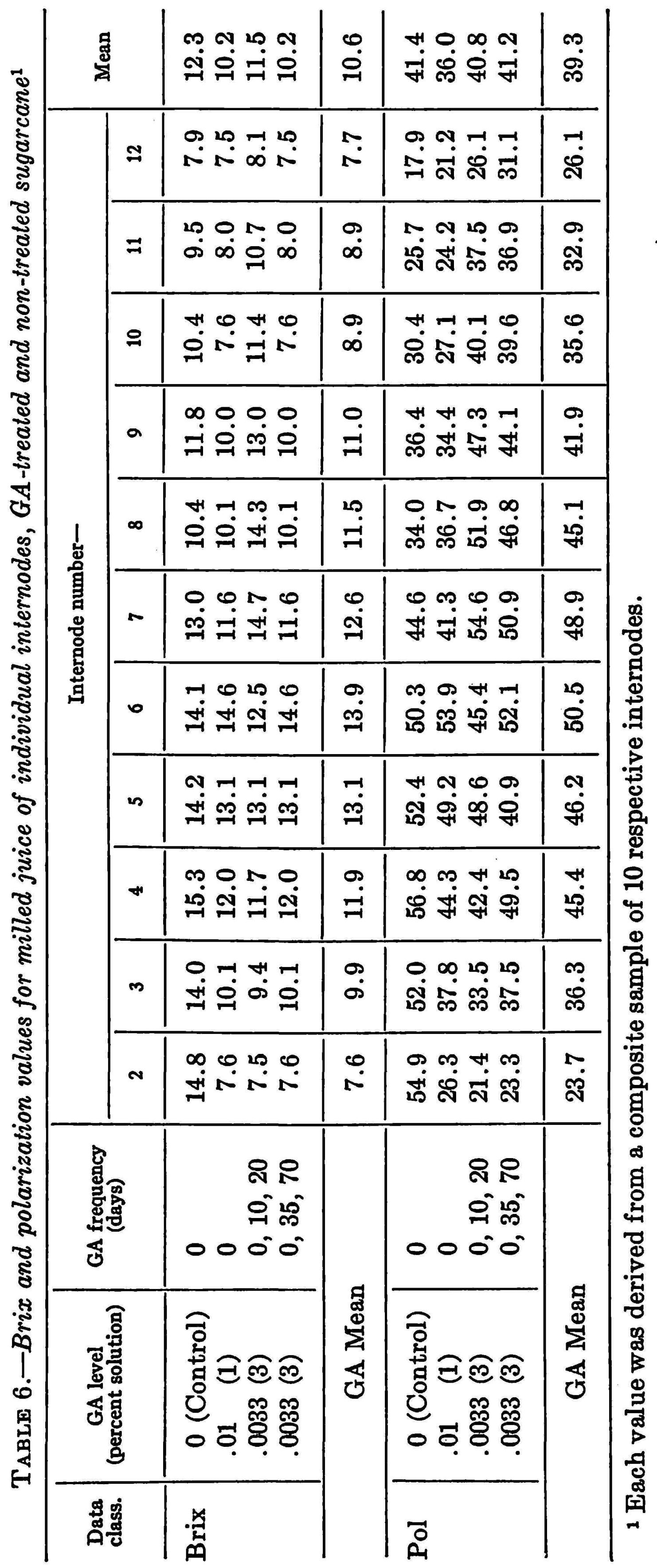


TABLE 7.-Sucrose content of milled juice from individual internodes of sugarcane treated with $G A^{1}$

\begin{tabular}{|c|c|c|c|c|c|c|c|c|c|c|c|c|c|c|c|c|c|}
\hline \multirow{2}{*}{$\begin{array}{c}\text { GA level } \\
\text { (percent solution) }\end{array}$} & \multirow{2}{*}{$\begin{array}{l}\text { GA frequency } \\
\text { (days) }\end{array}$} & \multicolumn{13}{|c|}{ Sucrose content, in mg./ml. of juice, for internode number- } & \multirow{2}{*}{ Mean } & \multirow{2}{*}{$\begin{array}{l}\text { Volume of } \\
\text { juice per } \\
\text { stalk (ml.) }\end{array}$} & \multirow{2}{*}{$\begin{array}{l}\text { Estimated } \\
\text { sucrose per } \\
\text { stalk (B.) }\end{array}$} \\
\hline & & 2 & 3 & 4 & 5 & 6 & 7 & 8 & 9 & 10 & 11 & 12 & 13 & 14 & & & \\
\hline 0 (Control) & $\mathbf{0}$ & 135 & 144 & 150 & 149 & 144 & 130 & 114 & 114 & 92 & 87 & 66 & 43 & 33 & 108 & 136 & 14.68 \\
\hline $.01 \quad(1)$ & 0 & 94 & 106 & 138 & 152 & 154 & 144 & 142 & 130 & 126 & 114 & 99 & 48 & 36 & 114 & 189 & 21.55 \\
\hline $.0033(3)$ & $0,10,20$ & 71 & 86 & 121 & 116 & 138 & 135 & 121 & 126 & 126 & 126 & 100 & 91 & 41 & 108 & 214 & 23.11 \\
\hline $.0033(3)$ & $0,35,70$ & 95 & 131 & 137 & 133 & 153 & 150 & 143 & 141 & 121 & 124 & 112 & 70 & 43 & 120 & 167 & 20.04 \\
\hline \multicolumn{2}{|c|}{ GA Mean } & 87 & 108 & 132 & 134 & 148 & 143 & 135 & 132 & 124 & 121 & 104 & 69 & 40 & 114 & 190 & 21.56 \\
\hline
\end{tabular}

1 Each value was derived from a composite sample of 10 respective internodes.

1 Tach value was derived from a composite sample of 10 respective internodes. 
period, based on mean sucrose values per internode and mean volume of juice obtained per stalk at the final harvest. It can be seen that among GA treatments the mean sucrose values per ml. of juice were already equal to or greater than controls, and that the juice volume was much greater due to the GA growth effects already discussed. As a result the sucrose produced

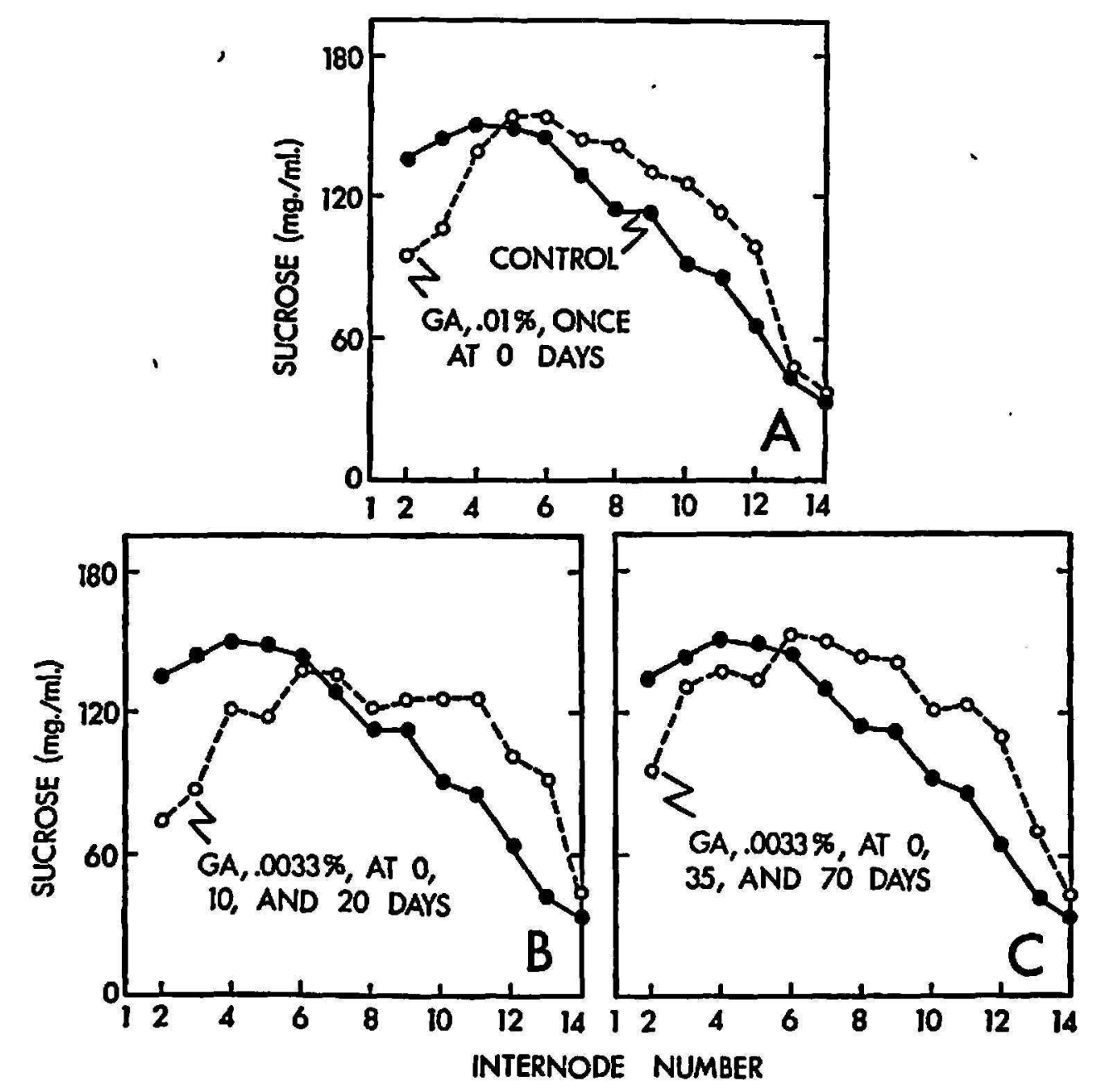

FrG. 5. Sucrose content of milled juice from individual internodes of GA-treated sugarcane.

per GA-treated stalk was roughly half again greater than that of the average control stalk.

\section{Growth vs. Sucrose Production}

A common understanding among sugar producers is that cane loses sugar when growing rapidly and accumulates sugar when growth is slackened. This is quite logical; however, as the present data indicates, it is not necessarily true. Several important concepts were brought forward that deserve analysis. 
First; the highest sucrose values were obtained as a result of growth stimulation plus an increased sucrose-forming potential. A glance at figure 5 does confirm that internodes already laid down or being laid down when GA was first applied lost heavily from sucrose reserves. Those plants making the most vigorous growth, i.e., those given multiple GA over a short time interval, lost more heavily than others. This agrees fully with accepted notions of growth rate vs. sucrose content. However, within a few weeks after GA application, all GA-treated plants began to accumulate more sucrose in the stalks than did controls. This trend continued even while growth rates remained at above-normal levels (tables 1 and 3 ). Especially significant is the fact that sucrose accumulated in stalks where no appreciable growth decline occurred at all, i.e., in response to short-term GA increments (fig. 5,B; fig. 2,B). The important concept here is that only so long as new growth was dependent upon stored sugar reserves did losses occur in the stalks. A few weeks later, while GA growth stimulation was still in progress, the plants were producing enough sugar to satisfy growth needs and to increase storage levels as well. Storage sucrose appears to have been lost only while cane was "tooling up" for greater production. Additional proof of this is found in the observation that GA applications delayed until 35 and 70 days did not cause storage losses (fig. 5,C).

A second concept is that GA increases the sucrose-synthesizing capability of sugarcane, and that this is reflected in the sucrose content and relative maturity of the stalks. As noted in our introduction, a photosynthetic GA effect was suggested by increases of leaf sucrose during earlier GA studies $(1,2,5)$. Evidence of GA-stimulated synthesis from fructose plus UDPG or G-1-P has also been recorded (9). However, our most conclusive prior evidence was gathered during recent controlled-illumination studies (10). By holding GA-pretreated plants in prolonged darkness, and then reexposing them to sunlight, an unusually powerful sucrose mechanism was demonstrated during the replacement of leaf photosynthates lost in darkness. Quite significantly, both fructose and glucose accumulations accompanied sucrose in the newly-illuminated leaves. A paper chromatogram illustrating these reducing sugars in the leaf extracts is reproduced in figure 6.

Paper chromatograms were prepared during the present study with clarified juice from individual internodes. The four chromatograms presented in figure 7 represent the control treatment and each of the three GA treatments. Internodal juice constituents from control stalks, figure 7,A, was limited almost entirely to sucrose in internodes two and three. These internodes were mature. At progressively higher internode numbers the tissues became less mature and proportionately greater amounts of reducing sugars appeared. The latter, fructose and glucose, constitute the two 
dark-staining spots corresponding to reference fructose and glucose, " $F$ and G", appearing at the left-hand side.

A most significant feature is the delayed appearance of reducing sugars in all GA-treated stalks (fig. 7,B, C, and D). The reader will note that for

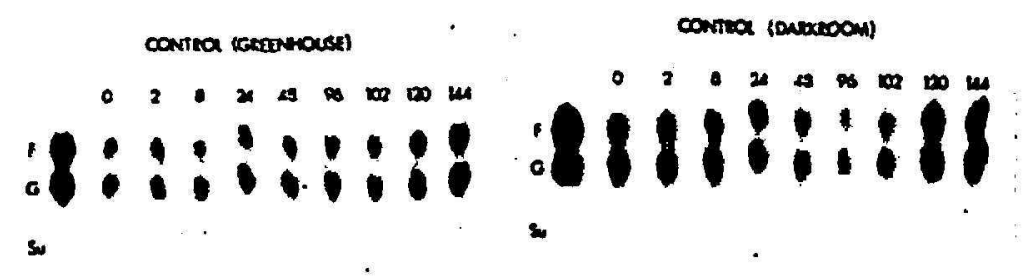

A B
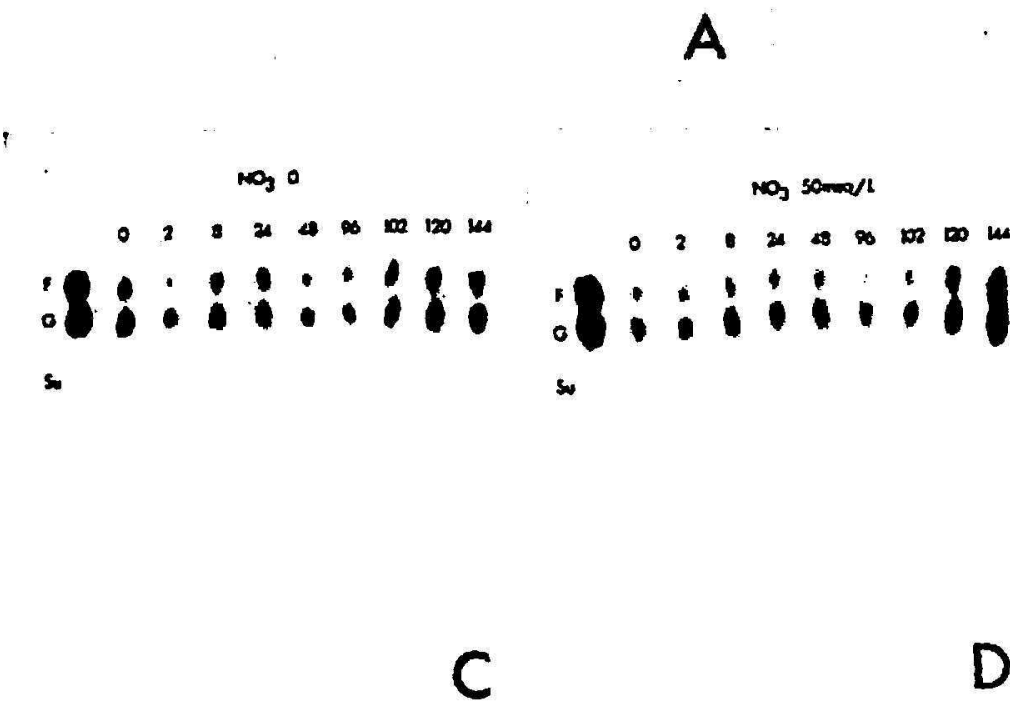

D

$\mathbf{E}$

Fra. 6.-Paper chromatograms illustrating fructose, glucose, and sucrose in aqueous leaf extracts from 2 control groups of sugarcane, and from sugarcane pretreated with variable $\mathrm{NO}_{3}$ and $\mathrm{GA}$ prior to differential light exp ssure. Numerals refer to hours of controlled illumination. The letters " $F$. ( $i$, and su" appearing at the lefthand margin signify reference fructose, glucose, and sucrose, respectively. Note the relatively heavy masses of fructose and glucose in ( $\mathrm{A} A$-pret rented plants (E) as compared to the greenhouse control (A).

the single GA treatment (fig. 7,B3) reducing sugars did not appear in appreciable quantities prior to internode 11. For closely-spaced and widely-spaced increments (fig. 7,C and D) major (quantities were delayed until internode nine or 10. The point to be appreciated here is that GA produced a maturation effect. This occurred over the same internode range, numbers four to nine, where GA produced tremendous growth activity. Maturation here is quite significant. An opposite effect was to be expected; one underscored by 
intense inversion, with the products fructose and glucose appearing in masses similar to those actually found in internodes 13 and 14 .

A final concept can be forwarded which is becoming increasingly attractive as GA studies continue. It is based on the GA-stimulation of leaf fructose

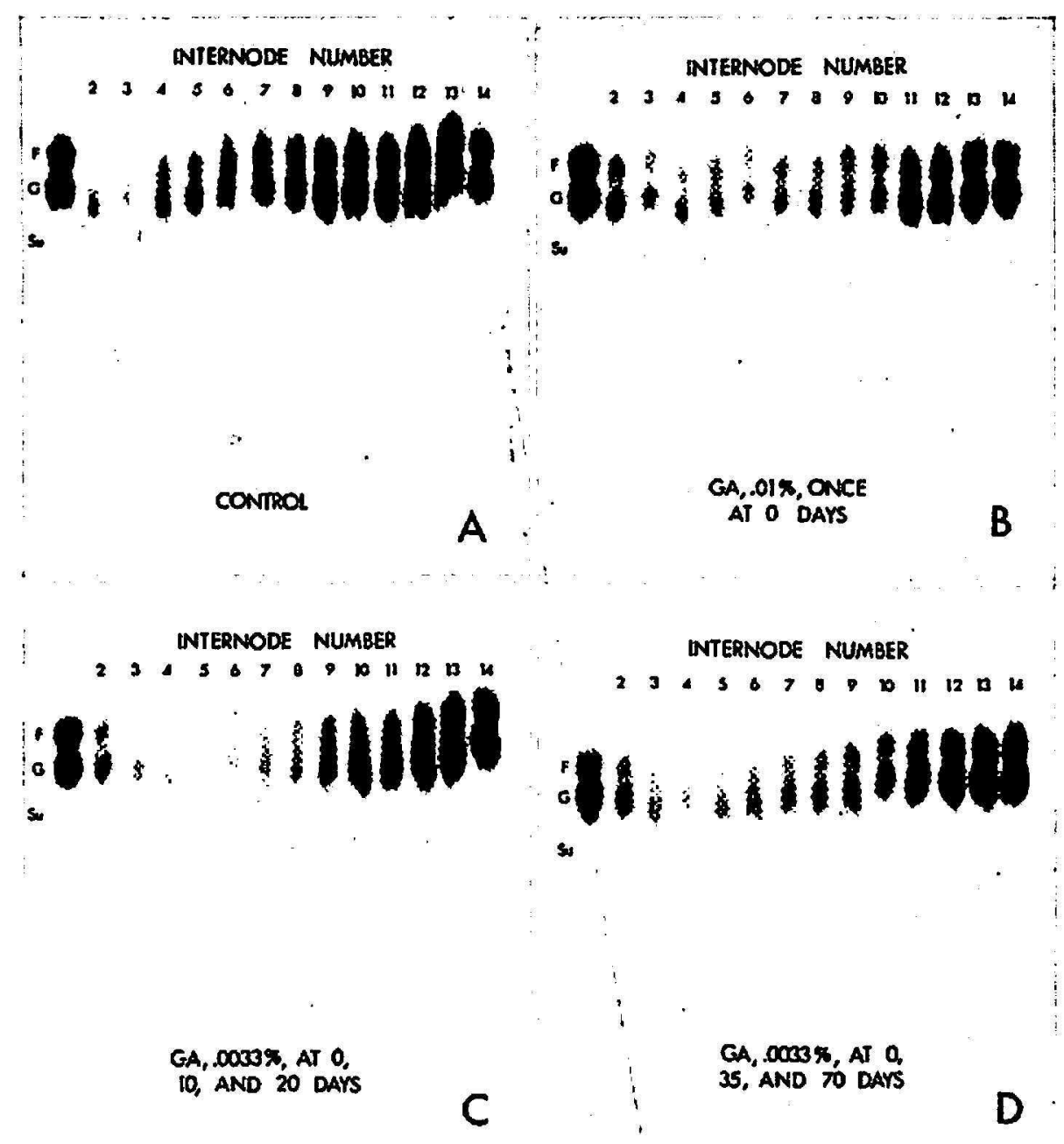

Frg. 7.-Paper chromatograms of clarified juice from internodes of GA-treated sugarcane. Numerals refer to specific internodes. The letters "F, G, and Su" appearing at the left-hand margin signify reference fructose, glucose, and sucrose, respectively. Note the relative absence of fructose and glucose in internodes 3 to 10 of GA-treated stalks (B, C, D) as compared to stalks of control plants (A).

and glucose, figure $6, \mathrm{E}$, and the relative absc.lce of these sugars in GAstimulated stalk tissues. Whereas it was felt for some time that GA increased sucrose, it was assumed that part of this sucrose was inverted and expended to meet the additional growth requirements. It now appears that an increased supply of reducing sugars from photosynthesis can cover much or all of the growth requirement without ever having to reside in the sugarcane stalk. If necessary, that fraction of the newly-formed sucrose passing to meristematic areas might possibly be inverted and its products 
utilized without the GA-stimulated plant having to draw upon sucrose reserves in mature storage tissues.

\section{GA Effects on Ratoon Production}

A consideration of no small importance to sugar growers is the continued production of vigorous ratoon crops after successive harvests are completed. In Puerto Rico the failure of ratoons to maintain a vigor characteristic of the initial planting often causes concern among growers who must decide whether a newly-released variety should be given expanded acreage. The eventual field usage of GA might conceivably bear upon this problem.

With this in mind, the number and weight of shoots from control and GA-treated plants was recorded 3 weeks after the final regular harvest. Data summarized in table 8 indicate that GA moderately increased ratoon

TABLE 8.-Post-harvest ratoon production by sugarcane as a function of the number and frequency of prior GA applications

\begin{tabular}{|c|c|c|c|}
\hline $\begin{array}{l}\text { GA level (percent } \\
\text { solution) }\end{array}$ & $\begin{array}{l}\text { Frequency applied } \\
\text { (days) }\end{array}$ & $\begin{array}{c}\text { Total number of } \\
\text { shoots }\end{array}$ & $\begin{array}{c}\text { Fresh meight } \\
\text { (g./shoot) }\end{array}$ \\
\hline $\begin{array}{l}0 \text { (Control) } \\
.01 \quad(1) \\
.0033(3) \\
.0033(3)\end{array}$ & $\begin{array}{l}0 \\
0 \\
0,10,20 \\
0,35,70\end{array}$ & $\begin{array}{l}396 \\
550 \\
500 \\
357\end{array}$ & $\begin{array}{l}3.71 \\
3.98 \\
3.80 \\
3.76\end{array}$ \\
\hline \multicolumn{2}{|c|}{ GA Mean } & 469 & 3.85 \\
\hline
\end{tabular}

number when given as a single dose or in closely-spaced increments and gave very slight weight increases for individual shoots. The additional shoots are possibly accountable to breakage of bud dormancy rather than increased initiation of new buds. Quite significantly, the use of widely-spaced GA increments failed to stimulate shoot production beyond control levels.

\section{Significance of GA Level and Timing Research}

As we implied earlier, a sugar industry seeking greater returns sometimes places "the cart before the horse". This could well be the case with GA.

Generally speaking, this study has shown that a tremendous amount of research remains to be accomplished at the greenhouse and laboratory level. We cannot begin to understand the physiological potential of GA on the basis of field trials alone. The groundwork must be laid where the individual cane plant is in fact grown and treated as an individual, in essence, as a horticultural entity.

It has been demonstrated that a broad versatility of action exists for a constant quantity of GA. Timing is of utmost importance, as is absolute 
concentration at the time of penetration. Taking first into account the concept that maximum growth must be attained through cumulative GA action, and second that growth reversion to subnormal levels will ultimately follow, the key physiological problem becomes one of controlling the two growth phases. The present study has laid some of the groundwork for control of the first phase.

\section{SUMMARY AND CONCLUSIONS}

A treatment-efficiency study was conducted in relation to growth and sugar activity of applied gibberellic acid (GA) in sugarcane. The work was performed at the greenhouse and laboratory level with plants grown in sand culture. All plants received an equal absolute amount of GA during varying periods of time. Three GA treatments were initiated at 10 weeks: $1, \mathrm{~A}$ single application of 0.01 percent; 2 , increments of 0.0033 percent each given at 0,10 , and 20 days; and 3 , increments of 0.0033 percent each given at 0,35 , and 70 days. Treatments were designed to test the theory that maximum growth must be obtained as a short-term cumulative effect, and that long-delayed increments are partially wasted against a growth reversion which follows GA growth stimulation. A second objective was to prove that GA-induced growth is accompained by an increased sugar-synthesizing and sugar-accumulating capability, and to determine which of the frequency-concentration differentials was most effective for sugar production. Samples were taken at 2-week intervals over a period of 4 months for growth and sugar analyses.

The following results were obtained:

1. Growth data for total green weights, internode elongation, internode thickening, and millable-stalk weights revealed positive effects for all GA treatments as compared to controls.

2. Maximum green weight, internode length, and stalk weight was achieved with three $\mathrm{GA}$ increments given over a short-time interval $(0,10$, and 20 days). Widely-spaced increments produced no appreciable growth increases over those of a single application.

3. Internode elongation reached a maximum average of 8.6 inches with short-term increments, while a single GA application produced a maximum of 7.4 inches. With increments the positive GA effect extended over a timegrowth period of seven internodes, while the single-dose effect extended over four internodes. None of the treatments affected the total internode number.

4. All GA-treated plants experienced growth reversion toward subnormal levels as indicated by internode-length data. While the slope of growth decline was constant, the initiation of decline was much delayed by use of short-term GA increments. For long term-increments the 35- and 70-day applications encountered strong growth reversion already in progress. The 
latter increments succeeded in checking decline temporarily, while the decline itself prevented each increment from achieving its stimulatory potential. Net growth increases from delayed applications were not appreciably greater than those from a single application.

5. Reversion of internode elongation was accompanied by increased lateral growth, i.e., internodal thickening. Lateral growth was greatest for the single GA treatment. However, only with short-term increments did lateral growth compensate for losses in length. On the basis of millable-stalk weight, the most important growth criterion, the closely-spaced increments were most successful in countering growth reversion.

6. Lengthwise splitting of internodes was a common problem among plants given all GA in a single dose. This damage was seldom noted when GA was applied in increments. Contrary to an earlier assumption, the splitting did not appear to be a function of rapid growth rate, since by far the most rapid growth was achieved with closely-spaced increments. It is concluded that weakened stalk structure results from a temporarily unbalanced growth physiology, which, in turn, is sensitive to absolute GA level at the moment of tissue penetration.

7. Brix, polarization, and direct sucrose analyses of milled juice from whole stalks showed that GA had either accomplished modest sugar increases per unit of storage tissue, or had maintained levels comparable to control plants during the 4 months of study. Coupled with the additional growth produced by GA, all GA-treated plants yielded significantly more sugar than did controls. For total sucrose production the short-term increments were superior to other GA treatments, largely on the basis of superior growth. The frequency of GA increments had less effect on sucrose than on growth.

8. Analysis of juice from individual internodes showed that those internodes already laid down at the time of initial GA treatment suffered severe sucrose losses. After about 4 weeks GA-treated cane began accumulating sucrose above control levels, even though high growth activity was progressing simultaneously. Thus the utilization of stored sucrose by the GAstimulated plants was an interim measure, one apparently designed to "hold the line" while the new sugar-forming potential could be geared to growth requirements.

9. It was concluded that GA stimulation of sugar synthesis is of sufficient magnitude to satisfy added growth needs, and to send additional sucrose into storage as well.

10. Based on earlier findings of GA-increased levels of leaf fructose and glucose, and on the lack of inversion products in GA-treated stalks, it was proposed that sugar requirements for GA-stimulated growth are satisfied 
by a portion of the freshly-formed sucrose diverted toward the meristematic area.

11. Paper chromatography of juice from individual internodes revealed an apparent maturation effect of GA on the stalk segments. Reducingsugar levels were notably lessened in GA-treated internodes, as compared to controls, while sucrose was generally increased above the fourth internode. The single GA application was more effective in this respect than either of the increment treatments.

12. The importance of exploring a broad range of physiological-biochemical GA potentials, at the greenhouse and laboratory level, is briefly discussed.

\section{RESUMEN Y CONCLUSIONES}

Un estudio sobre la eficiencia de los tratamientos con ácido giberélico (AG) y su influencia en el crecimiento y contenido de azúcar se llevó a cabo en caña de azúcar. El trabajo se hizo al nivel de invernadero y en un laboratorio con plantas cultivadas en arena. Todas las plantas recibieron una cantidad total igual de AG durante períodos variables de tiempo. Se aplicaron tres tratamientos de AG a las 10 semanas de haberse sembrado las plantas: 1, Una sola aplicación de una solución al 0.01 por ciento; 2 , aplicaciones de una solución al 0.0033 por ciento a los 0,10 y 20 días; y 3, aplicaciones de una solución al 0.0033 a los 0,35 y 70 días. Los tratamientos fueron diseñados para poner a prueba la teoría de que un crecimiento máximo puede obtenerse como un efecto cumulativo a corto plazo, y que la influencia de las aplicaciones retrasadas por largo tiempo se pierden en parte debido a la reversión del crecimiento que sigue al estímulo causado por el AG. Un segundo objetivo fue probar que el crecimiento inducido por el AG va acompañado por una capacidad para aumentar la síntesis y la acumulación de azúcar, y también determinar cuál de las dos es la más efectiva para la producción de azúcar, si la frecuencia de la aplicación o la concentración de la solución. Las muestras para determinar el crecimiento y para el análisis del azúcar se tomaron a intervalos de 2 semanas, durante un período de 4 meses. Se obtuvieron los siguientes resultados:

1. Los datos de crecimiento para el peso verde total, alargamiento y engrosamiento del entrenudo y peso de la caña aprovechable comercialmente demostraron efectos positivos de todos los tratamientos con el AG, al compararlos con las plantas testigo.

2. Se logró un máximo en el peso verde y en la longitud del entrenudo y peso de la caña aprovechable para molienda con tres aplicaciones de $\mathbf{A G}$ dadas a intervalos cortos (0, 10 y 20 días). Las aplicaciones ampliamente espaciadas no produjeron aumentos apreciables de crecimiento alguno sobre los alcanzados con una sola aplicación. 
3. El alargamiento del entrenudo alcanzó un promedio máximo de 8.6 pulgadas con aplicaciones a intervalos cortos, mientras que una sola aplicación lo alargó a 7.4 pulgadas como máximo. El efecto positivo de las aplicaciones divididas de AG se extendió durante un período en que se combinaron los factores de tiempo y crecimiento hasta alcanzar siete entrenudos, mientras que el efecto de una sola dosis se extendió hasta cuatro entrenudos. Ninguno de los tratamientos afectó el número total de entrenudos.

4. Todas las plantas tratadas con AG experimentaron una reversión del crecimiento hacia niveles subnormales, tal como se indica en los datos referentes al largo de los entrenudos. A pesar de que el declive descendente del crecimiento fue constante, la iniciación del descenso se retrasó mediante las aplicaciones de AG a corto plazo. Para las aplicaciones a largo plazo, las que se hicieron a los 35 y 70 días se tropezaron con la fuerte reversión de crecimiento ya en progreso. Las últimas aplicaciones consiguieron retardar temporalmente el descenso mientras que éste por su parte evitó que cada nueva aplicación lograra su potencial como estimulante. Los aumentos netos en el crecimiento producidos por las aplicaciones retrasadas no fueron apreciablemente mayores que los producidos con una sola aplicación.

5. La reversión del alargamiento de los entrenudos fue acompañada de un aumento lateral en su crecimiento, es decir, el engrosamiento. El crecimiento lateral fue mayor en el caso de una sola aplicación de AG. Sin embargo, solamente con aplicaciones a corto plazo se compensó la pérdida de la longitud con un crecimiento lateral. El criterio más importante respecto al crecimiento, basado en el peso de la caña aprovechable para moler, indica que las aplicaciones a intervalos cortos fueron las que más éxito tuvieron en contrarrestar la reversión del crecimiento.

6. El rajarse el entrenudo a todo lo largo fue un problema corriente en las plantas a las cuales se les aplicó el AG en una sola dosis. Este daño rara vez sucedió cuando las aplicaciones de AG se dividieron. Contrario a lo que se suponía anteriormente, el rajarse no pareció ser causado por un crecimiento rápido, por cuanto el más rápido se logró con aplicaciones hechas a intervalos bien cortos. Se concluye que la débil estructura de la caña en tales casos es el resultado de un desbalanceado crecimiento fisiológico temporal, el cual es a su vez sensitivo al nivel absoluto del AG en el momento de penetrar al tejido.

7. Los análisis de Brix, polarización y sacarosa del jugo de las cafias demostraron que el AG o habia logrado modestos aumentos de azúcar por unidad de tejido reservante o mantenido niveles comparables a los de las plantas testigo durante los 4 meses del estudio. Además de un crecimiento adicional, producido por el $\mathrm{AG}$, todas las plantas asi tratadas también rindieron significativamente más azúcar que las plantas testigo. Basándose principalmente en un mayor crecimiento, las aplicaciones a corto plazo 
fueron superiores a los demás tratamientos con AG en cuanto a la producción total de sacarosa. La frecuencia de las aplicaciones de AG tuvo un efecto menor en la producción de sacarosa que en el crecimiento.

8. El análisis del jugo de los entrenudos individuales demostró que aquellos que ya existían cuando se inició el tratamiento de AG sufrieron pérdidas severas en sacarosa. La caña tratada con $\mathrm{AG}$ comenzó a acumular sacarosa sobrepasando los niveles de las plantas testigo alrededor de 4 semanas después del tratamiento, aun cuando seguían creciendo simultáneamente. La utilización de la sacarosa almacenada en las plantas estimuladas por el AG era por lo tanto una acción interina, dirigida aparentemente a sostenerse hasta tanto el nuevo potencial para la formación de azúcar pudiera ajustarse a los requisitos para su crecimiento.

9. Se concluyó que el estímulo generado por el AG para la síntesis del azúcar es de suficiente magnitud para satisfacer tanto las necesidades adicionales de crecimiento como también para enviar sacarosa adicional de reserva.

10. Basándose en previos hallazgos respecto a los aumentos en los niveles de fructosa y glucosa causados por el AG y en la falta de productos invertidos en la caña así tratada, se propuso que los requisitos para un crecimiento estimulado por el AG son satisfechos por una porción de la sacarosa recién formada y desviada hacia las áreas meristemáticas.

11. La cromatografía sobre papel del jugo de los entrenudos individuales reveló un efecto de aparente madurez a causa del AG en los segmentos del tallo. Los niveles de los azúcares reductores fueron marcadamente reducidos en los entrenudos que se trataron con $\mathrm{AG}$ en comparación con los de las plantas testigo, mientras que la sacarosa aumentó por lo general después del entrenudo número 4. Una sola aplicación de AG fué mucho más efectiva en este respecto que cualquiera de las demás aplicaciones divididas.

12. La importancia de investigar más extensamente los potenciales fisiológicos y bioquímicos del AG, tanto al nivel de laboratorio como al del invernadero, se discute brevemente.

\section{LITERATURE CITED}

1. Alexander, A. G., Interrelationships of gibberellic acid and nitrate in sugar production and enzyme activity of sugarcane, J. Agr. Univ. P.R. ER (1): 19-28, 1968.

2. - Effects of combined silicon and gibberellic acid on enzyme behavior and sucrose content of immature sugarcane, Proc. Int. Soc. Sugarcane Technol., 18: 522-31, 1969.

3. - Relationships of gibberellic acid to water and phosphorus in the growth, sugar production, and enzyme behavior of sugarcane, J. Agr. Univ. P.R. 63 (3): 149-66, 1969.

4. Alexander, A. G., Montalvo-Zapata, R., and Ashok Kumar, Enzyme-silicon 
studies of gibberellic acid-treated sugarcane during the post-growth stimulatory phase, J. Agr. Univ. P.R., 54 (1): 82-95 1970.

5. Alexander, A. G., Montalvo-Zapata, R., and Gene L. Spain, Prevention of sugarcane flower production with Paraquat, gibberellic acid, and silicon: Chemical effects on growth, sucrose production, and enzyme activity, J.Agr. Univ. P.R. In preparation.

6. Bull, T. A., The effects of temperature, variety, and age on the responses of Saccharum spp. to applied gibberellic acid, Aust. J. Agr. Res. 16: 77-84, 1964.

7. Conference on coordination of basic research programs of sugarcane agriculture, David North Research Centre, Queensland, Australia. Personal communication with Dr. A. J. Vlitos.

8. Tanimoto, T., and Nickel, L. G., Re-evaluation of gibberellin for field use in Hawaii, Rept. Haw. Sugar Technol., 25th annual meeting, pp. 184-80, 1966.

9. Alexander, A. G., The potential of sugarcane to produce sucrose, Proc. Int. Soc. Sugar Cane Technol. 18: 1-24, 1969.

10. Alexander, A. G., Kumar, A., Montalvo-Zapata, R., and Gene L. Spain, Responses of sugarcane enzymes to variable light: Variable illumination studies of invertase, ATP-ase, and amylase in plants experiencing nitrate- and gibberellic acid-induced stress, J. Agr. Univ. P.R., 54 (3): 448-76 1970.

11. Coleman, R. E., Todd, E. H., and Coleman, O. H., The effects of gibberellic acid on sugarcane, Proc. Int. Soc. Sugar Cane Technol. 10: 588-603, 1959.

12. Cardini, C. E., Leloir, L. F., and Chiriboga, J., The biosynthesis of sucrose, J. Biol. Chem. 214: 149-55, 1955.

13. Personal communication with Dr. John R. Seip, Superintendent, Audubon Sugar Factory, Louisaina State University, Baton Rouge, La.

14. Dube, S. K., and Nordin, P., Isolation and properties of sorghum alpha-amylase, Arch. Biochem. Biophys. 94: 121-7, 1961.

15. Chang, H., and Lin, R. C., The effect of gibberellic acid on the growth of spring paddy sugarcane, Report of the Taiwan Sugar Experiment Station 28: 121-6, 1961 .

16. Villareal, E. P., and Santos, O., Test on the effect of Gibrel upon the growth and yield of sugar cane, Proc. Philippines Sugar Technol., 6th Ann. Convention, pp. 87-91, 1958.

17. Harber, A. H., and Talbert, N. E., Photosynthesis in gibberellin-treated leaves Plant Physiol. 88: 152-3, 1957.

18. Hayashi, T., The effect of gibberellin treatment on the photosynthetic activity of plants, 4th Int. Conference on Growth Regulation, Iowa State University Press, Ames, Iowa, pp. 579-88, 1961. 